\title{
Prenatal Yoga
}

\author{
Farida Tandi Bara \\ Email: faridatandibara@gmail.com \\ Prodi D3 Kebidanan, STIKes Bhakti Pertiwi Luwu Raya, Indonesia \\ Jl. Imam Bonjol No 27 Kota Palopo \\ Telp/Fax. (0471) 3307444
}

\begin{abstract}
Abstrak
Kehamilam merupakan kondisi fisiologis. Selama kehamilan terjadi ketidaknyaman yang merupakan akibat dari proses adaptasi fisiologis sistem tubuh ibu terhadap kehamilannya. Ketidaknyaman yang masih dalam batas normal dapat berubah menjadi tidak normal karena ketidaksiapan ibu menjalani kehamilannya. Ibu hamil yang sehat akan berdampak pada perkembangan janin yang optimal. Persiapan persalinan juga dimulai sejak kehamilan. Prental yoga merupakan upaya promotif dan preventif untuk meningkatkan kesehatan ibu agar dpat beradaptasi dengan perubahan fisik dan psikologis selama kehamilan dan mempersiapan proses persalinan.Prenatal yoga diikuti oleh ibu hamil mulai trimester 2 , dilakukan setiap selasa dan jumat selama 90 menit.. Setiap sesi dimulai dari latihan pranayama (pernafasan), latihan asana dan kegel. Pada bagian akhir dilakukan latihan relaksasi dan afrmasi positif. Hasil yang dapat disimpulkan dari kegiatan ini adalah meningkatnya kebugaran fisik ibu hamil dan meningkatkan kesiapan psikologis hamil.
\end{abstract}

Kata Kunci: ibu hamil; prenatal yoga.

\begin{abstract}
Pregnancy is a physiological condition. During pregnancy there is discomfort which is a result of the physiological adaptation process of the mother's body system to her pregnancy. Discomfort that is still within normal limits can turn out to be abnormal due to the mother's unpreparedness for her pregnancy. Healthy pregnant women will have an impact on optimal fetal development. Labor preparation also starts from pregnancy. Prental yoga is a promotive and preventive effort to improve the health of the mother so that she can adapt to physical and psychological changes during pregnancy and prepare for labor. Prenatal yoga join by pregnant women starting from the second trimester, done every Tuesday and Friday for 90 minutes. Each session starts with pranayama (breathing) practice, asana practice and kegel exercise. At the end, a relaxation and positive affirmation exercise was carried out. The results achieved in this activity are (1) increased physical fitness of pregnant women. (2) increasing the psychological readiness of mothers.
\end{abstract}

Keywords: pragnancy; prenatal yoga.

\section{Pendahuluan}

Kehamilan merupakan kondisi fisiologis yang memerlukan perhatian khusus. Ketidaksiapan fisik dan mental ibu hamil dapat menyebabkan kondisi tidak normal selama kehamilan. Ibu hamil sehat akan menyebabkan tumbuh kembang anak yang optimal ${ }^{1}$.

Target SDGs pada tahun 2030 adalah mengurangi rasio angka kematian ibu hingga kurang dari 70/100.000KH. Sampai saat ini penyebab kematian ibu masih perdarahan, pre eklampsi/eklampsi dan infeksi ${ }^{2}$. Komplikasi persalinan diatas dapat terjadi pada semua ibu hamil baik yang mempunyai factor risiko atau yang tidak mempunyai faktor risiko. Upaya promotif dan preventif dilakukan dengan meningkatkan kesehatan ibu hamil 
dan melakukan deteksi dini ${ }^{3}$. Bidan berperan penting dalam upaya peningkatan kesehatan ibu hamil dan melakukan deteksi factor risiko untuk penanganan selanjutnya.

Penyebab utama kematian ibu dapat dideteksi dan dicegah melalui ANC yang teratur ${ }^{4}$. Deteksi adanya factor risiko dan risiko tinggi pada kehamilan dilakukan pada semua kehamilan karena setiap kehamilan beresiko memgalami komplikasi. Menyiapkan fisik dan mental ibu hamil selama proses kehamilan akan mereduksi keluhan selama kehamilan dan mempersiapkan ibu memasuki proses persalinan ${ }^{1}$. Selama kehamilan terjadi ketidaknyaman yang merupakan akibat dari proses adaptasi fisiologis sistem tubuh ibu terhadap kehamilannya. Mual, muntah, pusing sering dialami pada trimester pertama akibat peningkatan hormone progesterone ${ }^{5}$. Pada trimester kedua dan ketiga tubuh ibu akan mendeposit cadangan lemak untukpersiapan menyusui sehingga BB ibu akan bertambah. Dan ditrimester ketiga, terjadi adaptasi postur tubuh ibu terhadap pembesaran uterus ibu dan untuk persiapan proses pesalinan. Keluhan yang sring timbul pada trimester ini adalah bengkak pada kaki, kesemutan, sering buang air kecil dan rasa tidak nyanan pada daerah pinggul $^{6}$.

Menyiapkan ibu hamil secara fisik dan psikologis menghadapi kehamilan dan persalinannya dapat dilakukan dengan berbagai cara. Salah satu dengan melakukan yoga selama hamil. Yoga yang dilakukan disesuaikan dengan keadaan ibu hamil atau prenatal yoga ${ }^{7}$ (Pujiastuti Shindu, 2015). Yoga selama hamil akan mengurangi kecemasan, menguatkan dan melenturkan otot, memperbaiki postur dan menenangkan ibu hamil. Dari literature diketahui manfaat prenatal yoga terhadap pengurangan ketidaknyamanan selama kehamilan, memperbaiki pernafasan dan sirkulasi darah, memperlancar proses persalinan dan mengurangi masalah selama post partum ${ }^{8}$

Dari diskusi yang dilakukan dengan bidan puskesmas Ma'rang, diketahui bahwa terjadi peningkatan rujukan ibu bersalin karena berbagai sebab. Penyebab utama karena persalinan lama. Tindakan untuk meningkatkan daya tahan ibu dengan pemberian tablet zat besi. Namun diketahui untuk memasuki persalinan dibutukan kesiapan fisik dan psikologis. Sehingga dibutuhkan persiapan fisik dan psikologis ibu.

\section{Metode}

Solusi yang ditawarkan dalam meningkatkan kesiapan fisik dan psikologis ibu hamil selama proses kehamilan dan persalinan adalah dengan melakukan senam yoga kehamilan. Untuk mendapatkan manfaat seperti yang diuraikan diatas, latihan yoga kehamilan dilakukan secara rutin. Latihan yoga terdiri dari:

a. Prayanama (latihan pernafasan)

b. Asana dan kegel (latihan kekuatan dan kelenturan otot)

c. Relaksasi

Setiap latihan yoga kehamilan, dilakukan selama 90 menit dan dilakukan 2 kali dalam seminggu.

Dengan latihan senam yoga ibu hamil yang rutin serta sesi nteraktif sebelum kelas dimulai diharapkan akan tercapai target luaran sebagai berikut:

1. Meningkatnya kebugaran fisik ibu hamil yang diharapkan dapat mengurangi keluhan ketidaknyaman selama 
kehamilan dan secara fisik siap menghadapi proses persalinan

2. Dengan latihan pernafasan, konsentrasi dan relaksasi dapat meningkatkan kesiapan psikologis ibu menghadapi persalinan sehingga proses persalinan dapat berlangsung normal dan lancer

3. Meningkatnya pemahaman dan pengetahuan ibu hamil tentang proses kehamilan melalui sesi interaktif. Topik pembahasan akan lebih focus pada permasalahan ibu selama hamil.

\section{Hasil dan Pembahasan}

Kelas yoga ibu hamil dilaksanakan setiap hari selasa dan Jumat jam $09.00 \mathrm{~s} / \mathrm{d} 10.30$ wita. Sesi latihan dibagi menjadi 3 sesi ;

1. Latihan Pranyama 15 menit

2. Latihan Inti 50 menit

3. Relaksasi 15 menit.

Diawal kelas yoga dilakukan interaktif tentang keluhan ibu hamil, jika ada keluhan atau pertanyaan, diskusi singkat akan membahas tentang keluhan ibu tersebut. Diskusi ini akan diteruskan dalam grup senam yoga ibu hamil melalui media sosial whatsapp.

\section{Gambar. Kelas yoga}

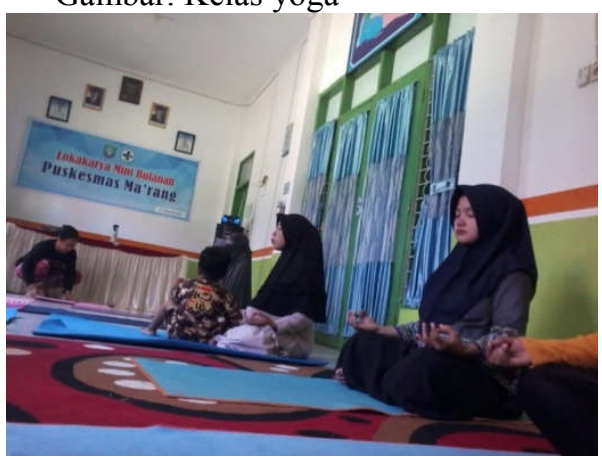

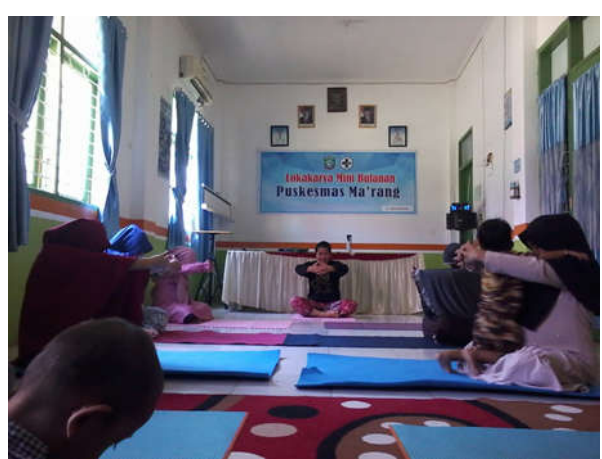
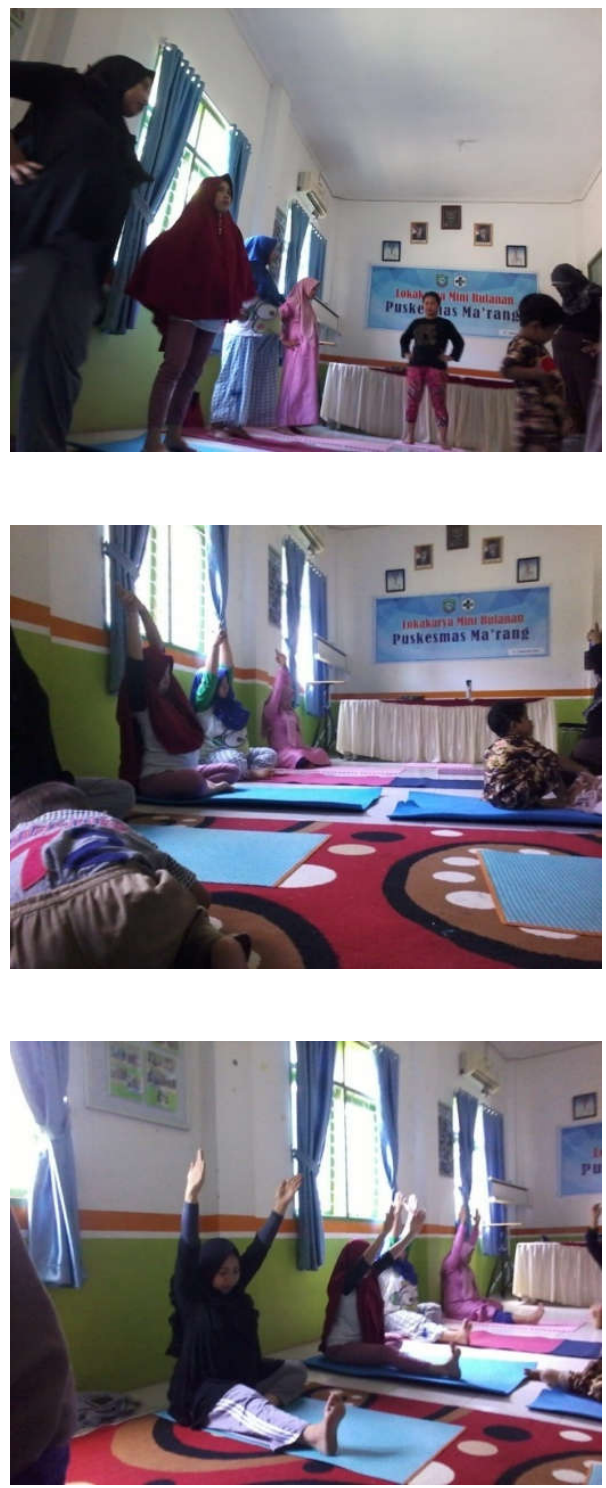


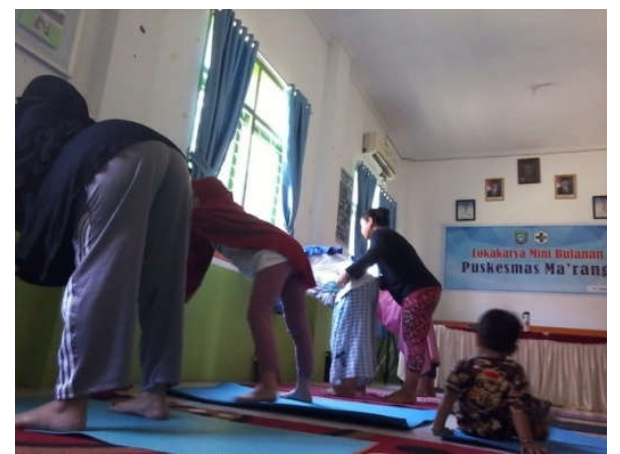

Notulen pelaksanaan dan absensi akan dijalankan setelah sesi latihan

Kehamilan menyebabkan ketidaknyamanan yang disebabkan oleh adaptasi fisologis selama kehamilan. Keluhan ini muai dari intensitas rendah sampi berat. Dan bisa berubah menjadi kondisi patologis.

Prenatal yoga melatih konsentrasi ibu dengan pernafasan diafragma.Latihan sguad dan kegel untuk menguatkaan otot dasar panggul serta otot paha berguna saat proses persalinan. Selama melakukan penguatan, ibu hamil dimotivasi untuk melakukan sampai ujung kemampaannya dan tidak terpengaruh dengan ibu hamil lainnya. Menegenali diri sendiri dan kemampuan akan membantu ibu tetap rileks selama latihan. Ini akan menambah kepercaayaan diri ibu hamil.

Latihan pernafasan pada sesi awal akan membantu mengurangi swing emosi yang sering dirasakan ibu hamil karena perubahan hormonal. Mengurangi kecemasan dan lebih fous pada diri sendiri. Pada sesi akhir latihan (15 menit) dilaukan latihan relaksasi, juga berfungsi mengurangi kecemasan ibu. Terhubung dengan janin dan memberikan afirmasi positif terhadap diri sendiri serta janinnya.

Dengan rutinitas senam yoga, manfaat akan dirasakan oleh ibu selama masa kehamilan dan masa persalinan.

\section{Kesimpulan}

Dari 6 bulan yang direncanakan, karena pandemic Covid-19 kegiatan prenatal yoga dilaksanakan hanya 10 minggu. Hasil yang dicapai dapat dilihat dari antusias ibu hamil berlatih dan beberapa yang melahirkan selama periode tersebut. Hasil yang dicapai pada kegiatan ini adalah ${ }^{(1)}$ kebugaran fisik ibu hamil meningkat, ${ }^{(2)}$ kesiapan psikologis ibu meningkat.

\section{Daftar Pustaka}

[1] Sitti Tyastuti, Asuhan Kebidanan Kehamilan, Modul Bahan Ajar ed.: PPSDMKKemenkes, 2016.

[2] Syafrawati. (2015) Pencapaian Tujuan Mdgs Bidang Kesehatan Di Indonesia. JKMA. [Online]. ttp://jurnal.fkm.unand.ac.id/inde x.php/jkma/article/view/1

[3] Sri Astuti, Didah, dan Neneng Martini, "Skrening Kehamilan Sebagai Upaya Peningkatan Kesehatan Ibu Hamil Di Desa Cipacing, Kecamatan Jatinangor, Kabupaten Sumedang" Dharmakarya, vol. 7, no. 4, pp. 285-289, Desember 2018.

[4] Ayu Indah Rachmawati, Ratna Dewi Puspitasari dan Eka Cania (2017). Faktor-Faktor Yang Memengaruhi Kunjungan Antenatal Care (ANC) Ibu Hamil. Medical Journal of Lampung University. [Online]. https://juke.kedokteran.unila.ac.i $\mathrm{d} /$ index.php/majority/article/vie $\mathrm{w} / 1748$ 
[5] Siti Azizah. (2015), Gambaran Keluhan Subjektif selama Kehamilan di Jakarta dan Faktor-faktor yang berhubungan. Tesis. [Online]. https://library.ui.ac.id/detail?id= 20417245\&lokasi=lokal\#parent HorizontalTab2

[6] Helen Varney, Buku Ajar Asuhan, vol.2, 4th ed. Jakarta: EGC. Jakarta. 2007.

[7] Pujiastuti Shindu, Yoga Untuk Kehamilan Sehat, Bahagia dan Penuh Makna. Mizan, 2015.

[8] Pujiastuti Shindu. Panduan Lengkap Yoga: untuk Hidup Sehat dan Seimbang. Mizan, 2014. 